\title{
Investigation of the effectiveness of dehydrated corneal collagen barriers on corneal defects: An experimental rabbit model
}

\author{
Büşra KİBAR KURT ${ }^{1, a, ®}$, Ali BELGE ${ }^{1, b}$ \\ ${ }^{1}$ Aydın Adnan Menderes University, Faculty of Veterinary Medicine, Department of Surgery, Aydın, Turkey \\ a'ORCID: 0000-0002-1490-8832; ' ORCID: 0000-0003-3346-6926 \\ Corresponding author: busra.kibar@adu.edu.tr \\ Received date: 21.04.2020 - Accepted date: 28.07.2020
}

\begin{abstract}
The aim of this study was to evaluate the effect of collagen shield on epithelial wound healing in rabbit eyes. Adult New Zealand Albino rabbits were used in the study. All surgical procedures were carried out under general anesthesia. Superficial keratectomies of $6 \mathrm{~mm}$ in diameter were created in 40 eyes of 20 rabbits and they were separated into 3 groups as the control (CN), medical treatment $(\mathrm{CA})$ and collagen barrier $(\mathrm{CB})$ groups. In the $\mathrm{CN}$ group, 6 rabbits received $0.9 \% \mathrm{NaCl}$ drops. In the $\mathrm{CA}$ group, 7 rabbits received ciprofloxacin and acetylcysteine. In the CB group, a collagen shield was placed on corneal defect for 72 hours in 7 rabbits. Central corneal thickness was measured using an ultrasound pachymeter. Corneal thickness was determined before and at 72 and 96 hours after surgery. There was a significant increase (CA group: $\mathrm{P}<0.01, \mathrm{CB}$ group: $\mathrm{P}<0.001$ ) in corneal thickness at 72 hours. The wound size was evaluated immediately after the surgery, then at 72 and 96 hours. There was a significantly greater healing response in the collagen shield group $(\mathrm{P}<0.001)$ compared to the other groups. The earlier wound closure in the $\mathrm{CB}$ group may be due to protection and lubrication of the epithelial cells in the margins of the fresh wound. These findings suggest that the collagen shield may be useful when treating corneal surface conditions in which de-epithelialization is a component.
\end{abstract}

Keywords: Collagen barrier, collagen shield, cornea wound, rabbit.

\section{Kornea yaralarında dehidre korneal kollajen bariyerlerinin etkinliğinin araştırılması: Deneysel tavşan modeli}

Özet: Çalışmada tavşanlarda korneal yaraların iyileşmesinde korneal kollajen bariyer etkinliğinin araştırılması amaçlandı. Çalışmada yetişkin Yeni Zellanda Beyaz Tavşanı kullanıldı. Tüm cerrahi prosedürler genel anestezi altında gerçekleştirildi. Yirmi adet tavşanın 40 gözünde biyopsi kornea merkezinde $6 \mathrm{~mm}$ çapında süperfisiyal keratektomi yapıldı. Tavşanlar; kontrol $(\mathrm{CN})$, medikal tedavi (CA) ve kollajen bariyer (CB) olmak üzere 3 gruba ayrıldılar. Kontrol grubunda 6 tavşana \%0,9 NaCl damlatıldı. Medikal tedavi grubunda 7 tavşana siprofloksasin ve asetilsistein damla uygulandı. Kollajen bariyer grubunda ise 7 tavşanda kornea üzerindeki yarayı kapatacak şekilde 72 saatlik kollajen bariyer yerleştirildi. Merkezi kornea kalınlığı ultrasonografik pakimetre kullanılarak ölçüldü. Kornea kalınlığı ameliyattan önce ve sonra 72 ve 96. saatlerde ölçüldü. Yetmiş ikinci saate kornea kalınlığında önemli düzeyde bir artış belirlendi (CA group: $\mathrm{P}<0,01, \mathrm{CB}$ group: $\mathrm{P}<0,001$ ). Lezyonlu bölgenin belirlenmesi amaciyla kornea hasarı oluşturulduktan sonra 0,72 ve 96 . saatlerde ölçüm yapıldı. Kollajen bariyer kullanılan gruptaki iyileşme düzeyinin $(\mathrm{P}<0,001)$ diğer gruplara kıyasla iyi olduğu belirlendi. Hızlı iyileşmenin; kollajen bariyerlerin yapısı gereği epitel göçüne engel olmaması, korneayı nemli tutması ve iyileşmeye destek olması gibi özelliklerinden kaynaklı olabileceği düşünülmektedir. Bu bulgular 1şığında kollajen bariyerler, kornea hasarlarında epitelizasyonun sağlanmasında etkili ve kullanışlı bir sağaltım aracı olarak değerlendirilebileceği düşünüldü.

Anahtar sözcükler: Kollajen bariyer, kollajen kalkan, kornea yarası, tavşan.

\section{Introduction}

In the 1970s, collagen was applied as a therapeutic agent for wound healing in skin burns and ulcers (33). Collagen barriers developed in 1980 was used as a corneal bandage after radial and laser keratotomy operations (18). Rigid polymethylmethacrylate scleral contact lenses (28) and hydrogel bandage contact lenses have been used in a variety of clinical applications (9).
Eyelid movements prevent epithelial cell migration. Collagen barriers act as a barrier on the surface of the cornea, accelerates the migration of epithelial cells adjacent to the laceration area, reduces the healing time and may reduce stromal edema and leukocyte infiltration. Due to its transparency, it can slightly decrease vision (30). 
Collagen barriers are used for ocular surface protection following surgical operations and traumatic and non-traumatic corneal wounds. Collagen shields have always been recommended for the use of collagen barriers in clinical ophthalmological practice (34).

Antibiotics are widely used usually as drops in corneal wounds, but they can be cytotoxic, delay epithelization and cause hyperemia and chemosis on the ocular surface. Furthermore, they can also induce bacterial resistance $(3,31)$.

This study aimed to investigate the efficacy of collagen barrier in the early healing phase of aseptic corneal wounds without antibiotic use.

\section{Materials and Methods}

The study material consisted of 20 adult New Zealand white rabbits, each weighing 2-3 kg. The rabbits were maintained at $23 \pm 5{ }^{\circ} \mathrm{C}$ (relative humidity $60 \pm 10 \%$ ) with food and water ad libitum. All rabbits were kept under observation for 3 weeks prior to the experimental study. After thorough physical and ophthalmological examinations animals without any health problems were included in the study.

The study was conducted in the Small Animal Clinics of the Department of Surgery of Veterinary Faculty of Aydin Adnan Menderes University with the approval of ADÜ - HADYEK No. 64583101/028.

Corneal thickness measurement: Ultrasonographic pachymeter (Pocket II, Quantel) medical was used to measure corneal thickness (Figure 1) and the corneal thickness was measured 4 times, i.e. before the lesion was created, and at 0,72 and 96 hours after. The measurement result was obtained by averaging 5 measurements and the measurement records were transferred to the computer.

Fluorescein test: The corneal wounds were visualized using fluorescein and photographed at 0,72 and 96 hours. Fluorescein sodium (Fluorescite 10\% $100 \mathrm{mg} /$ $\mathrm{ml} 5 \mathrm{ml}$ ampoule, Alcon, USA) was dropped into the eye, and then washed with physiological saline $(0.9 \% \mathrm{NaCl}$ $500 \mathrm{ml}$ solution, Biofleks pvc bag). The photograph was taken under cobalt blue light applied through slit-lamp (Kowa, SL-15 portable slit-lamp). A ruler was used for each measurement.

Anesthesia: The rabbits were anesthetized by intramuscular injection of xylazine hydrochloride $(5 \mathrm{mg} /$ kg Xylazinbio 2\% $50 \mathrm{ml}$, Bioveta, Czech Republic) and ketamine hydrochloride $(35 \mathrm{mg} / \mathrm{kg} \mathrm{mg} / \mathrm{kg}$ Alfamine $10 \%$ $10 \mathrm{ml}$, Alfasan, The Netherlands). Oxybuprocaine hydrochloride (Oxybuprocaine, $4.5 \mathrm{mg} / \mathrm{ml}, 10 \mathrm{ml}$, Benoxinate, Liba) was used as a local anesthetic.

Surgical procedure: The ocular surface was cleaned with $3 \%$ boric acid solution, the eyelids speculum was applied and a circular shaped defect of $6 \mathrm{~mm}$ in diameter was established on the center of the cornea each rabbit using biopsy punch, corneal blade (MVR 19 gauge) and Alger Brush under sterile conditions (Figure 2).

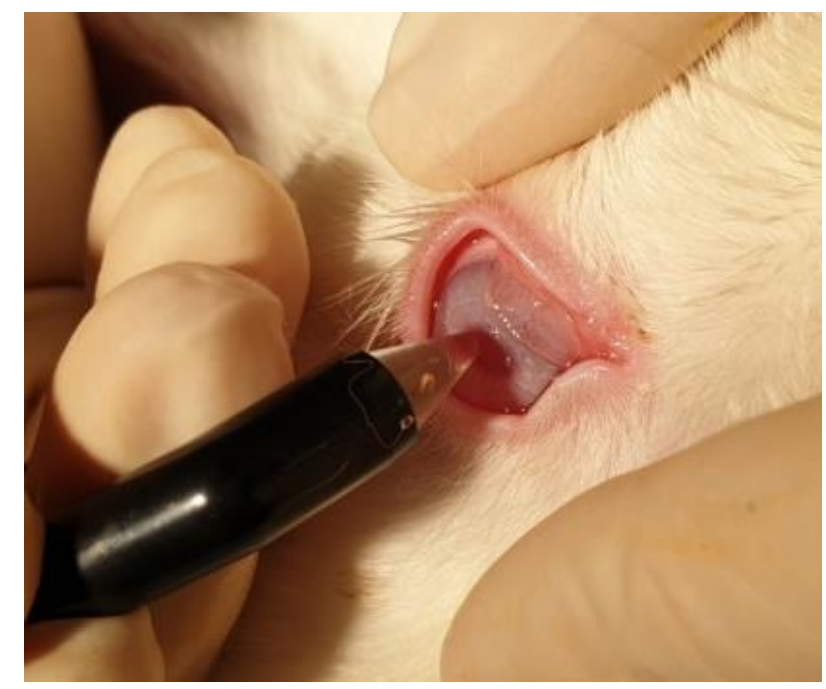

Figure 1. Measurement of corneal thickness.

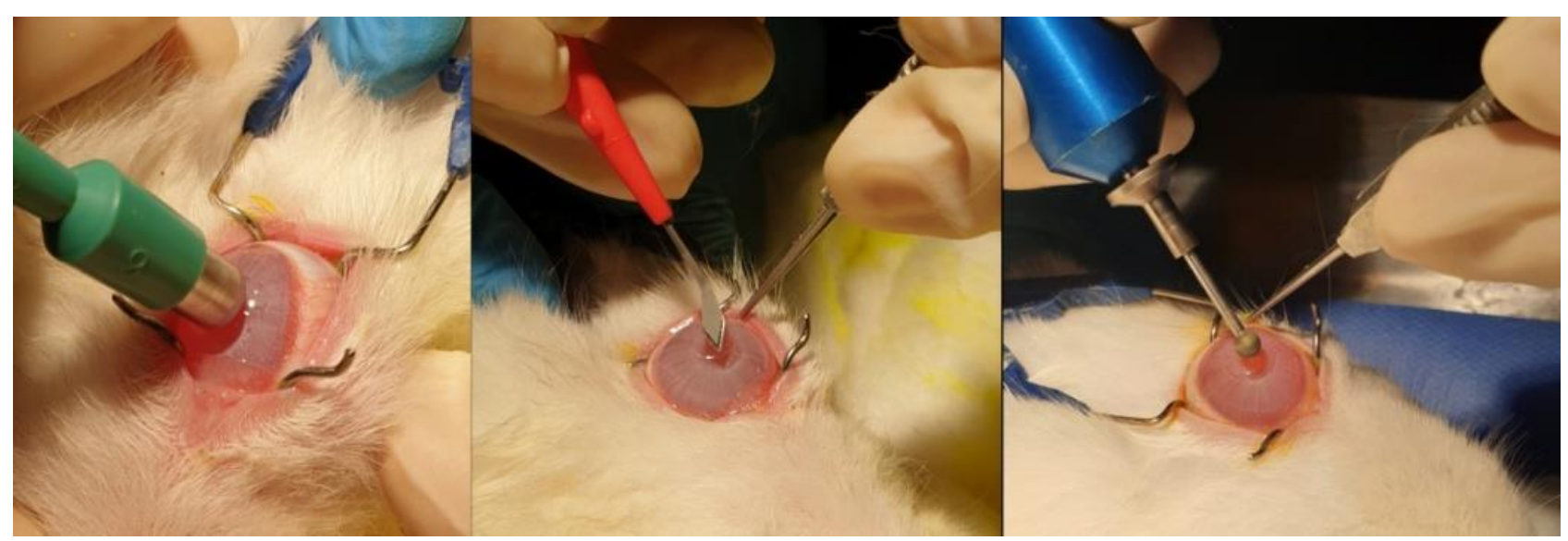

Figure 2. Making a circular defect area using $6 \mathrm{~mm}$ diameter biopsy punch, corneal blade (MVR 19 gauge) and Alger Brush. 


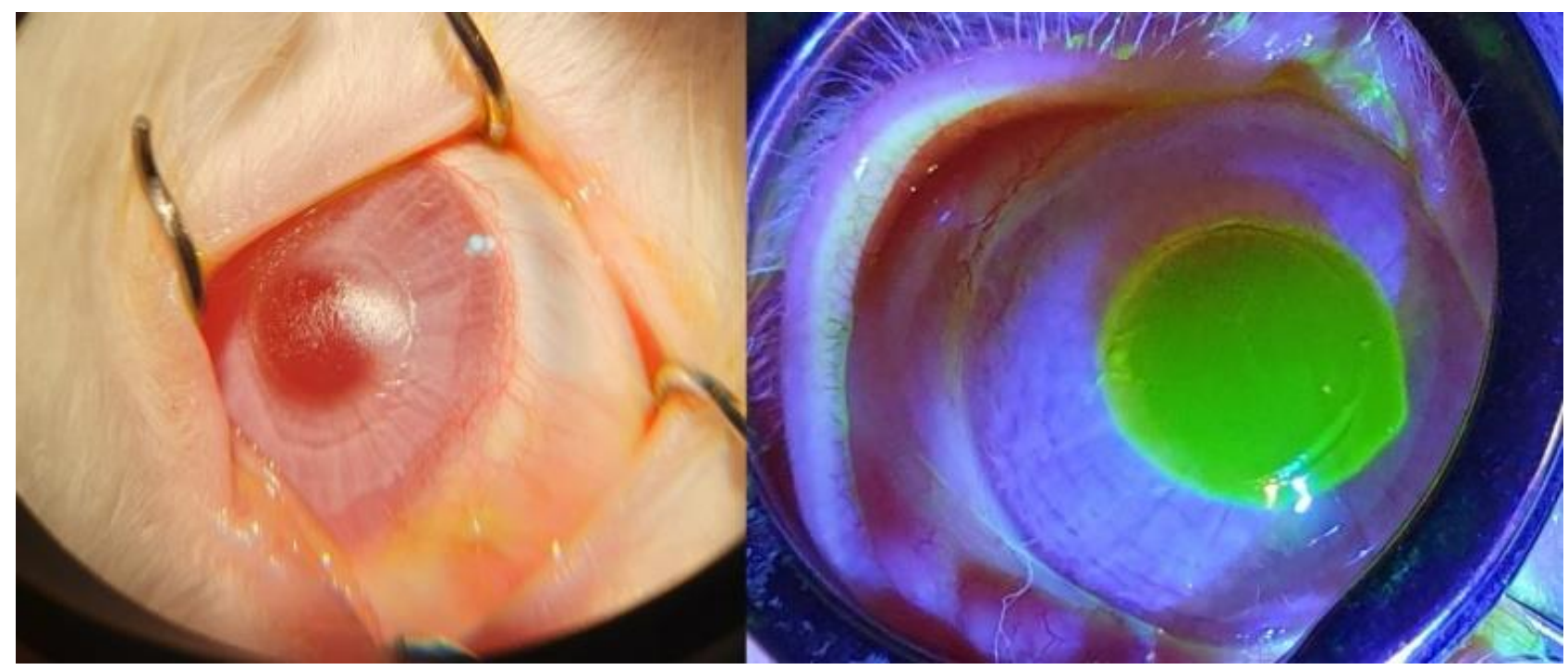

Figure 3. The appearance of the lesion created in the center of the cornea and fluorescein test after surgical procedure.

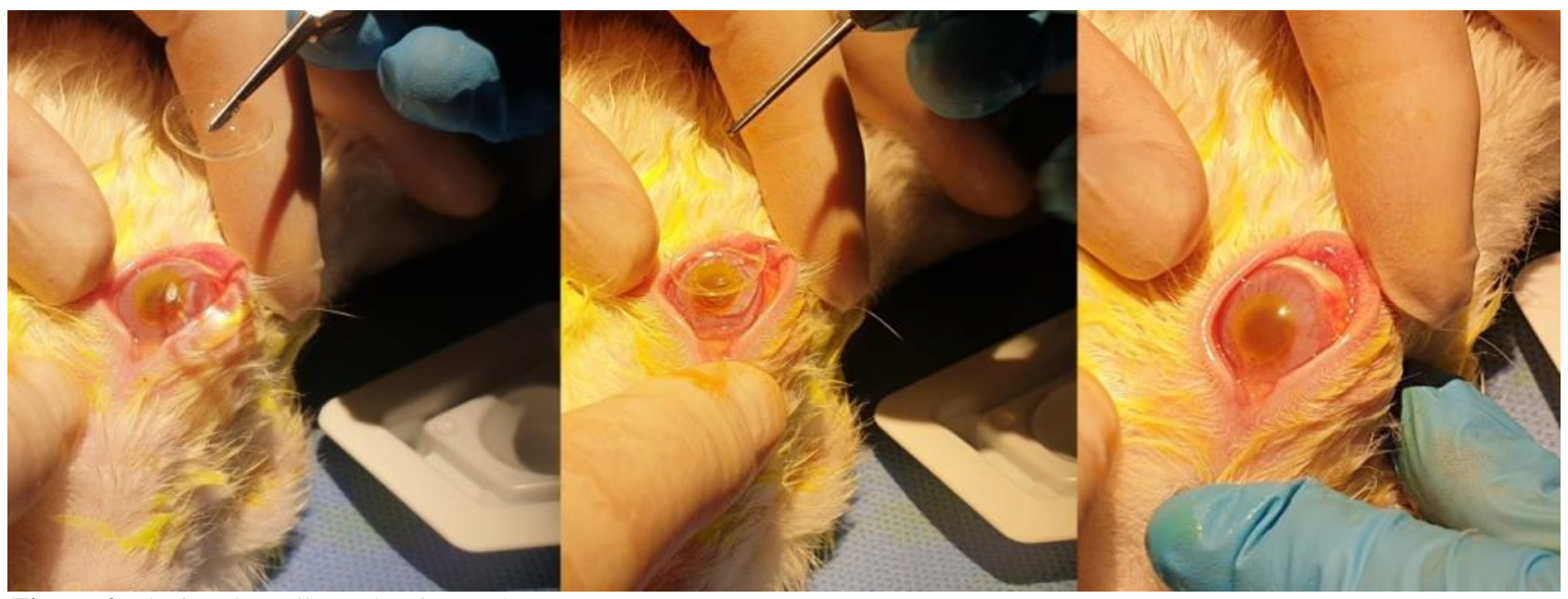

Figure 4. Placing the collagen barrier on the eye.

Fluorescein test: The corneal wounds were visualized using fluorescein and photographed at 0,72 and 96 hours. Fluorescein sodium (Fluorescite $10 \% 100 \mathrm{mg} /$ $\mathrm{ml} 5 \mathrm{ml}$ ampoule, Alcon, USA) was dropped into the eye and washed with physiological saline $(0.9 \% \mathrm{NaCl} 500 \mathrm{ml}$ solution, Biofleks PVC bag). The photograph was taken under cobalt blue light through slit-lamp. A ruler was used for each measurement (Figure 3).

Experimental design: The corneal lesion was created in both eyes of the rabbits as described previous reports $(4,7)$ because the traumatic lesion in the experimental model did not cover the whole eye and was not large enough to prevent the vision. So fewer rabbits were included in the study. During the trial period, all the animals had free access to food and water and the corneal defect did not cause any apparent discomfort. The rabbits were randomly assigned to the following groups: 1) $\mathrm{CN}$ group: 12 eyes of 6 rabbits received $0.9 \% \mathrm{NaCl}$ drops 4 times a day, 2) CA group: 14 eyes of 7 rabbits received ciprofloxacin (4 drops a day, Ciloxan $0.3 \% 5 \mathrm{ml}$ sterile ophthalmic solution, Novartis, Belgium) and acetylcysteine (2 drops a day, Brunac 5\%, $5 \mathrm{ml}$ sterile eye drops, Bio-Gen, Italy), 3) CB group: In all 7 rabbits, a 14.5 mm collagen shield (Vet Shield, OASIS ${ }^{\circledR} 72$, ABD) was wet with saline and placed on the corneal defect (Figure 4).

At the end of the study, all rabbits were sterilized and owned as pet animals after they were fully healed.

Calculation of defect area: The photographs obtained from the corneal defects were transferred to a computer and the defect area was measured using the polygon method and was recorded in $\mathrm{mm}^{2}$ using an image processing software (Image J 1.52a, Wayne Rasband National Institutes of Health, USA) (Figure 5). 


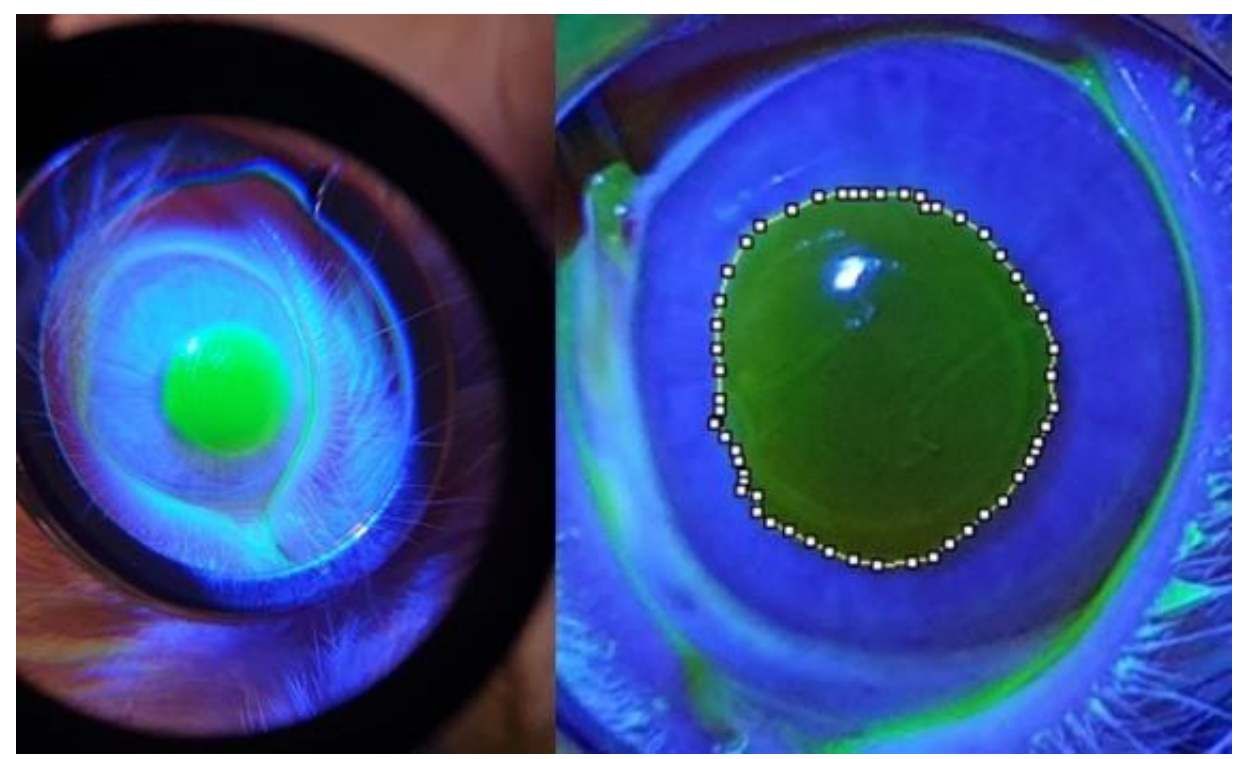

Figure 5. Measuring the lesion using Image J polygon method.

Table 1. The mean values of the corneal thickness according to time ( $\mu \mathrm{m}$, mean \pm standard error).

\begin{tabular}{|c|c|c|c|c|c|c|}
\hline \multicolumn{7}{|c|}{ Groups } \\
\hline & & $\mathbf{C N}$ & & CA & & CB \\
\hline Hours & $\mathbf{n}$ & $\overline{\mathbf{X}} \pm \mathbf{S} \overline{\mathbf{X}}$ & $\mathbf{n}$ & $\overline{\mathbf{X}} \pm \mathbf{S}_{\overline{\mathbf{X}}}$ & $\mathrm{n}$ & $\overline{\mathbf{X}} \pm \mathbf{S}_{\overline{\mathbf{X}}}$ \\
\hline Preoperative & 12 & $413.36 \pm 14.94$ & 14 & $375.14 \pm 10.58^{a}$ & 14 & $382.21 \pm 14.06^{\mathrm{ac}}$ \\
\hline 0 & 12 & $424.18 \pm 27.66$ & 14 & $388.71 \pm 14.46^{\mathrm{ac}}$ & 14 & $368.50 \pm 12.87^{\mathrm{a}}$ \\
\hline 72 & 12 & $471.73 \pm 28.30$ & 14 & $446.86 \pm 20.32^{b}$ & 14 & $468.29 \pm 18.33^{b}$ \\
\hline 96 & 12 & $445.73 \pm 27.54$ & 14 & $418.214 \pm 13.94^{c}$ & 14 & $419.79 \pm 16.84^{c}$ \\
\hline $\mathrm{P}$ & & & & $* *$ & & $* * *$ \\
\hline
\end{tabular}

$\mathrm{n}$ : Number of data; $\mathrm{a}, \mathrm{b}, \mathrm{c}$ : The difference between times in the same column is statistically significant.

**: $\mathrm{P}<0.01 ; * * *$ : $\mathrm{P}<0.001$

Statistical analysis: Data obtained in the study were analyzed statistically using SPSS 22 (Statistical Package for Social Sciences) software. Sample size estimation determined achieves a power of 0.81 . The Shapiro-Wilk and Levene tests were used to evaluate the assumptions of normal distribution and homogeneity of variances. Descriptive analyses were presented using mean $(\bar{X})$ and standard error $\left(\mathrm{S}_{\overline{\mathrm{X}}}\right)$ values. Repeated measures ANOVA was used to determine the statistical significance of time distribution. Post-hoc comparisons were made using Duncan's test. A value of $\mathrm{P}<0.05$ was regarded as statistically significant.

\section{Results}

Photophobia and epiphora ranging from mild to moderate were observed in all rabbits on the postoperative first day and these signs were not detected on the postoperative second day. Menace response, pupillary light, and dazzle reflexes were recorded as positive.
Mean corneal thicknesses are shown in Table 1. At 72 hours, corneal thickness increased in all groups compared to the first postoperative measurement (Figure $6)$. No significant difference was observed between the groups at the $72^{\text {nd }}$ and $96^{\text {th }}$ hours. Statistical differences were determined in the corneal thickness measurements at the different times in the $\mathrm{CA}(\mathrm{P}<0.01)$ and $\mathrm{CB}$ groups.

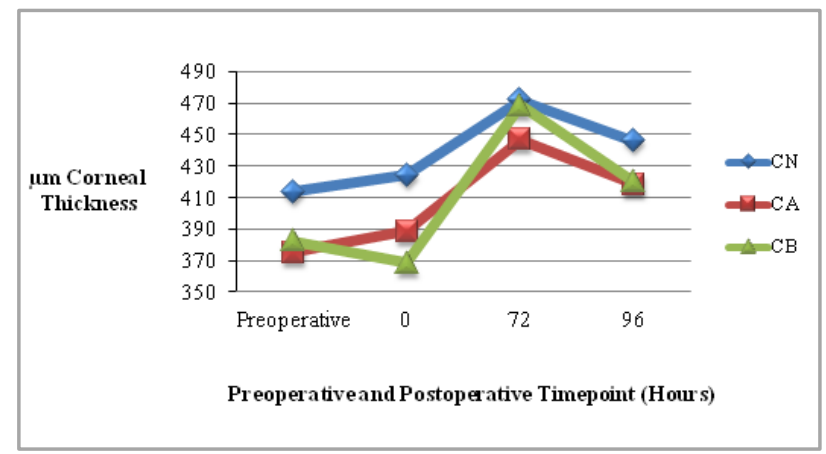

Figure 6. Change of corneal thickness obtained in groups over time. 
Mean corneal defect areas are shown in detail in the tables (Tables 2-3). Mean corneal defect areas were statistically different in all groups between 0,72 , and 96 hours. The defect size percentages for each group were averaged for each time point (Figure 7). There was a significantly greater healing response in the $\mathrm{CB}$ group than in the other groups $(\mathrm{P}<0.001)$ (Figure 8$)$.

It was observed that in some rabbits corneal defects recovered fully with a resultant of fluorescein negative opacity at 72 and 96 hours (Figure 9).

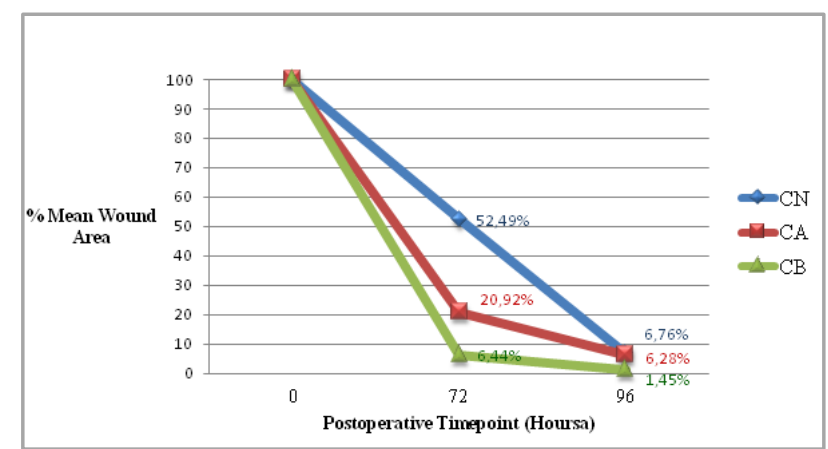

Figure 7. Mean wound areas (\%) of the groups over postoperative time.

Table 2. Change of the defect areas formed in the cornea according to time ( $\mathrm{mm}^{2}$, mean \pm standard error).

\begin{tabular}{|c|c|c|c|c|c|c|}
\hline & \multicolumn{6}{|c|}{ Groups } \\
\hline & \multicolumn{2}{|r|}{$\mathbf{C N}$} & \multirow{2}{*}{\multicolumn{2}{|c|}{$\frac{\mathbf{C A}}{\overline{\mathbf{X}} \pm \mathbf{S} \overline{\mathbf{X}}}$}} & \multicolumn{2}{|r|}{ CB } \\
\hline Hours & $\mathbf{n}$ & $\overline{\mathbf{X}} \pm \mathbf{S} \overline{\mathbf{X}}$ & & & $\mathbf{n}$ & $\overline{\mathbf{X}} \pm \mathbf{S}_{\overline{\mathbf{X}}}$ \\
\hline 0 & 12 & $32.129 \pm 1.58^{\mathrm{a}}$ & 14 & $31.41 \pm 1.33^{\mathrm{a}}$ & 14 & $29.01 \pm 0.92^{\mathrm{a}}$ \\
\hline 72 & 12 & $16.87 \pm 2.25^{\mathrm{b}}$ & 14 & $6.57 \pm 1.63^{\mathrm{b}}$ & 14 & $1.87 \pm 0.66^{\mathrm{b}}$ \\
\hline 96 & 12 & $2.17 \pm 0.46^{\mathrm{c}}$ & 14 & $1.97 \pm 0.48^{\mathrm{c}}$ & 14 & $0.42 \pm 0.18^{\mathrm{b}}$ \\
\hline $\mathrm{P}$ & & $* * *$ & & $* * *$ & & $* * *$ \\
\hline
\end{tabular}

n: Number of data; $a, b, c:$ The difference between times in the same column is statistically significant.

$* *$ : $\mathrm{P}<0.01 ; * * *$ : $<<0.001$

Table 3. Change of defect areas formed in the cornea over time $\left(\mathrm{mm}^{2}\right.$, mean \pm standard error).

\begin{tabular}{|c|c|c|c|c|}
\hline & \multicolumn{4}{|c|}{ Hours } \\
\hline & & 0 & 72 & 96 \\
\hline Groups & $\mathbf{n}$ & $\overline{\mathbf{X}} \pm \mathbf{S}_{\overline{\mathbf{X}}}$ & $\overline{\mathbf{X}} \pm \mathbf{S} \overline{\mathbf{X}}$ & $\overline{\mathbf{X}} \pm \mathbf{S} \overline{\mathbf{X}}$ \\
\hline $\mathrm{CN}$ & 12 & $32.129 \pm 1.58$ & $16.87 \pm 2.25^{\mathrm{a}}$ & $2.17 \pm 0.46^{\mathrm{a}}$ \\
\hline $\mathrm{CA}$ & 14 & $31.41 \pm 1.33$ & $6.57 \pm 1.63^{\mathrm{b}}$ & $1.97 \pm 0.48^{\mathrm{a}}$ \\
\hline $\mathrm{CB}$ & 14 & $29.01 \pm 0.92$ & $1.87 \pm 0.66^{\mathrm{c}}$ & $0.42 \pm 0.18^{\mathrm{b}}$ \\
\hline $\mathrm{P}$ & & & $* * *$ & $* *$ \\
\hline
\end{tabular}

$\mathrm{n}$ : Number of data; $a, b, c$ : The difference between groups in the same column is statistically significant.

$* *: \mathrm{P}<0.01 ; * * *: \mathrm{P}<0.001$.

Figure 8. Corneal wound healing. CN: Control group; $\mathrm{CA}$ : Ciloxan and acetylcysteine group; CB: Collagen barrier; h: hour.

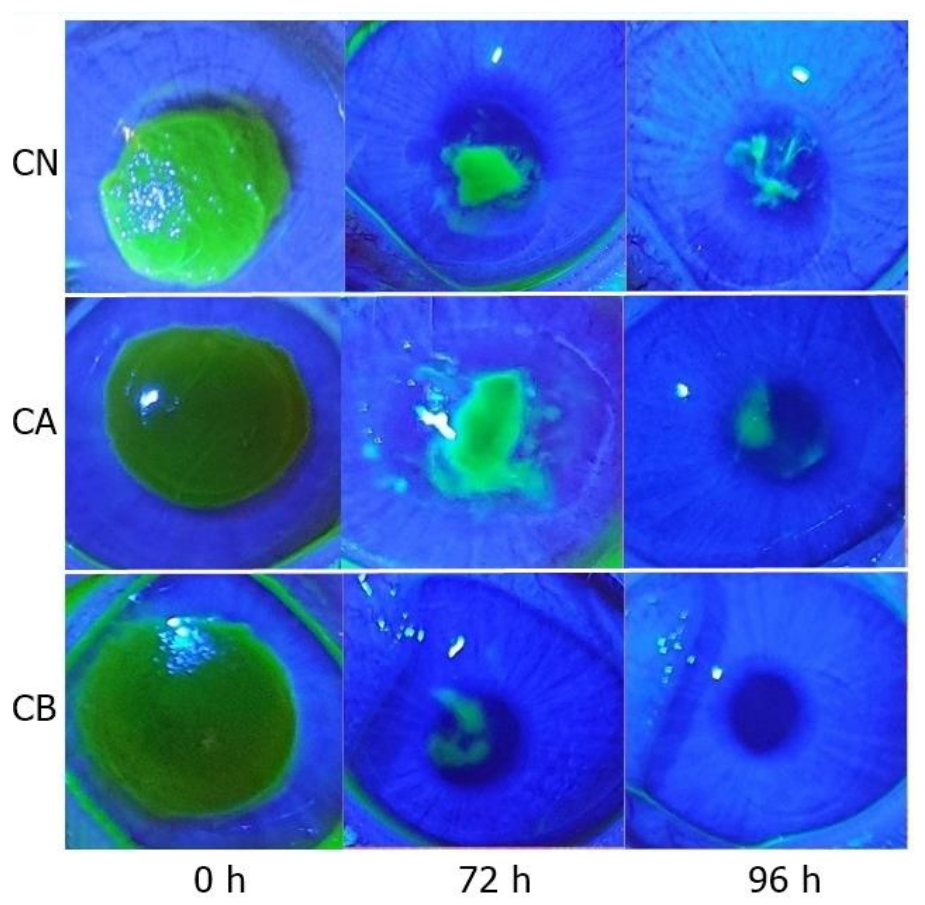




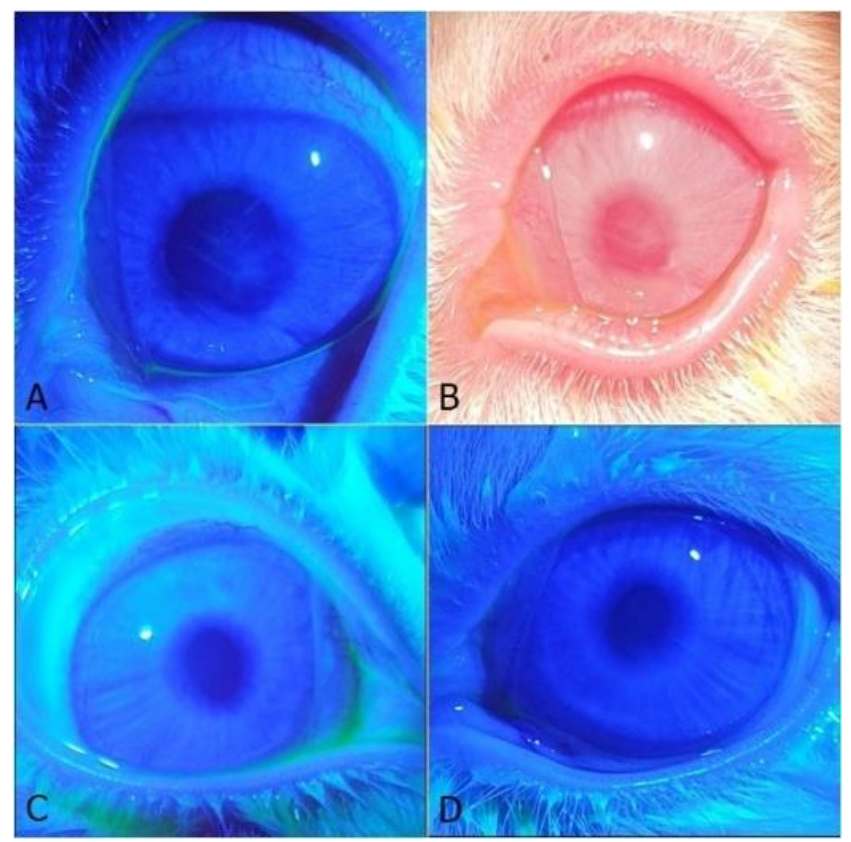

\section{Discussion and Conclusion}

Laboratory animals, such as rabbits, rats, and mice are widely used in ophthalmic research. The rabbit model is frequently preferred especially in experimental studies of the cornea $(6,8,12,15,22)$. The presented study was planned to investigate the usability of the collagen barrier in veterinary medicine. Considering the indivisible structure of the collagen barrier, the rabbit eye was very suitable for the study.

There are different methods of creating corneal defects form linear to circular shape lesion $(7,15,23,24$, 30). In the present study, the corneal epithelial defects were created with aids of punch biopsy, and cornea blade and Alger brush. This method was found to be cheap as well as simple, and especially the usage of the biopsy punch was quite beneficial and enables to create unique corneal defects in all subjects. Thus, it can be considered that this method will be preferred by researchers in future experimental studies.

Many studies $(1,23)$ showed that superficial corneal defects can recover within 48-72 hours due to epithelial proliferation and have also emphasized that the $72^{\text {nd }}$ hour is critical in determining the morphological and pathological changes during the healing process of the cornea $(2,10,15)$. In the current study, considering the previous studies, the defects induced were assessed using pachymeter and fluorescein and photographed at 0, 72 and 96 hours after the induction. These time intervals are found to be sufficient to monitor changes in corneal defect healing and corneal thickness.

In the literature, there are more data on rabbit corneal thickness. Researchers have reported the corneal thickness in rabbits to be between 338 and $430 \mu \mathrm{m}$ at its center (29). Ultrasonographic pachymeter is generally used because it
Figure 9. Corneal opacity, CN group, rabbit no 3, left eye, $96^{\text {th }}$ hour (A and B). Healed cornea, CB group, rabbit no 4, right (C) and left (D) eye, $96^{\text {th }}$ hour.

is cheap, easy to apply and repeatable. Contact with the cornea is the most important disadvantage (19). In this study, ultrasonographic pachymeter was applied by the same surgeon, and similar corneal thicknesses to those of previous studies were obtained and in this respect no difference between the groups (CN: 413.36; CA: 375.14 and CB: $382.21 \mu \mathrm{m}$ ) was also determined.

In the present study, corneal thickness reached the highest level at 72 hours and decreased the normal level at 96 hours. The increase in corneal thickness is thought to be the result of proliferation of epithelial cells at approximately 24 hours after injury, persists for up to 72 hours and returns to normal after the third day $(10,15)$. It has been reported that corneal thickness increased in measurements taken at 0,15 and 30 minutes after removal of corneal epithelium ( $410.38 \mu \mathrm{m}, 435.56 \mu \mathrm{m}$ and 458.44 $\mu \mathrm{m}$, respectively) (25). The changes in corneal thickness determined in the study are consistent with the literature data $(10,15)$. The increase in thickness is thought to be due to cell proliferation-migration and edema.

Despite many protection mechanisms, any traumarelated ocular surface damage or local or systemic immunosuppressions may induce the normal flora of the eye to become a source of infection. In treatment, it is necessary to select broad-spectrum antibiotics (17), thus when planning the experimental design, in CA group ciprofloxacin which is a widely used antibiotic in veterinary medicine was applied. No evidence of infection was observed in the $\mathrm{CN}$ group. In this case, it may be considered that antibiotics are not required in noninfectious, traumatic or non-traumatic cornea wounds.

Collagen-rich layers form the corneal tissue (21). Collagen, which has an important place in wound healing, collapses in corneal injuries due to its large concentration 
in the cornea and prevents the destruction of deeper layers. Local collagenases which are released from the damaged epithelium, keratocytes, macrophages and polymorphonuclear leukocytes increase in corneal damage and cause severe destruction of collagen as well as the corneal structure. Acetylcysteine, which has an anticollagenic effect and activates the formation of collagen fibrils in the treatment of corneal wounds $(11,20,26)$ was used as $3 \%$ in addition to ciprofloxacin in the CA group. Previous studies in dogs have reported that this concentration alone is suitable for the treatment of different corneal lesions $(11,13)$. The healing rate was higher in the CA group compared to the $\mathrm{CN}$ group. It was used in combination with ciprofloxacin in the CA group. Therefore, the rate of recovery cannot be attributed just to the positive action of acetylcysteine.

The use of a bandage lens has long been the preferred method for the treatment of corneal wounds. In a normal open eye, the partial oxygen pressure in the tear film layer is $155 \mathrm{~mm} \mathrm{Hg}$, and while the eyelids are closed it reduces 40-50 mm Hg (14). Using lenses lowers oxygen pressure further and causes epithelial hypoxia, resulting in corneal neovascularization (27). Collagen barriers have sufficient oxygen permeability for the metabolism of the corneal epithelium compared to other lenses. In the study, no evidence of neovascularization was observed. Research on the use and effectiveness of dehydrated corneal collagen barrier is becoming increasingly widespread (20, 33). Infection is a potential complication in the use of hydrophilic lenses in patients with epithelial or stromal defects. The disposability and solubility of the collagen barriers eliminate this risk $(14,27)$. The present study was planned to investigate the potential benefits as well as the practical application of the collagen barrier alone in the early period (96 hours) for the repair of corneal defects compared to classical treatment. In the presented study, no infection and neovascularization were detected indicating that the collagen barrier does not have disadvantages seen in the other type lenses.

During the study period, it was observed that in $\mathrm{CN}$ and CA groups the repeated application of eye drops caused a loss of time and labor whereas in the CB group the collagen barrier had benefits of ease of application and time saving.

Collagen is preferred as a wound healing agent in wounds and ulcers and acts as a support for corneal epithelial cells. Collagen barriers have long been used in human medicine to protect the ocular surface in corneal lesions. Previous studies have shown that wound closure time was shorter in the collagen barrier groups compared to untreated control $(7,30)$. The studies on the effectiveness of collagen barriers and therapeutic contact lenses in mechanical post-corneal debridement have demonstrated that this barrier eases epithelial cells migrating to the region and also protect epithelial proliferation from the mechanical movements of the eyelid (7, 30, 32). Eshar et al. (5) reported that collagen barrier was successful in the treatment of a rabbit with a chronic bilateral ulcer. Collagen barriers are also used in surgically induced, traumatic or non-traumatic corneal wounds to protect the ocular surface. Some studies on rabbits showed that it increases re-epithelialization in epithelial defects and keratotomy wounds, keeps the cornea moist and reduces stromal inflammation and edema. Collagen barrier promotes stromal healing by limiting keratocyte loss and reducing potential subepithelial fibrosis (34). In a study of cats by Croix et al. (16) which used a 72-hour form of collagen barrier (Vet Shield, OASIS $\left.{ }^{\circledR}\right)$, it was reported that the use of the collagen barrier after keratotomy increased the recovery rate.

In the present study, the classical treatment group (CA) and control group $(\mathrm{CN})$ were compared with the collagen barrier group (CB). According to the fluorescein test performed at 72 hours, the defect areas were determined as $16.87 \pm 2.25 \mathrm{~mm}^{2}$ in the $\mathrm{CN}$ group, $6.57 \pm$ $1.63 \mathrm{~mm}^{2}$ in the CA group and $1.87 \pm 0.66 \mathrm{~mm}^{2}$ in the CB group. From these data, a statistically significant difference $(\mathrm{P}<0.001)$ was detected between the groups and this difference was found to be between $\mathrm{CN}$ and $\mathrm{CB}$ groups where the largest defect area was seen in the first and smallest in the later group. In the $96^{\text {th }}$ hour measurements, defect areas were measured as $2.17 \pm 0.46$ $\mathrm{mm}^{2}$ in the $\mathrm{CN}$ group, $1.97 \pm 0.48 \mathrm{~mm}^{2}$ in the CA group and $0.42 \pm 0.18 \mathrm{~mm}^{2}$ in the $\mathrm{CB}$ group. The size of defect reduction in the $\mathrm{CB}$ group was found to be significantly lower as compared to the $\mathrm{CN}$ and $\mathrm{CA}$ groups $(\mathrm{P}<0.001)$, which shows that the healing rate was faster in the $\mathrm{CB}$ group compared to the other groups (Figure 7 and Table 3 ). These findings show that the collagen barrier alone accelerates wound healing inconsistent with other clinical and experimental studies $(5,7,16,30,32,34)$.

In conclusion, the results of this study showed that collagen barriers support epithelial migration, reduce the corneal wound area, reduce keratocyte loss and subepithelial fibrosis, and promote stromal healing. It is clear that medical treatment of corneal injury is long-term and tiring for patients and animal owners. The collagen barrier can be applied readily, eliminating the need for frequent application of eye drops, which is especially important in busy owners and in aggressive animals. In cases of corneal ulcers/wounds, collagen barrier can be recommended as a practical and effective treatment tool instead of eye drops.

\section{Acknowledgements}

This research article was summarized from the first author's PhD thesis. 


\section{Financial Support}

This research received no grant from any funding agency/sector.

\section{Ethical Statement}

This study was approved by Aydın Adnan Menderes University Animal Research Ethics Committee (ADÜHADYEK) (64583101/028).

\section{Conflict of Interest}

The authors declared that there is no conflict of interest.

\section{References}

1. Atiba A, Wasfy T, Abdo W, et al (2015): Aloe vera gel facilitates re-epithelialization of corneal alkali burn in normal and diabetic rats. Clin Ophthalmol, 9, 2019-2026.

2. Carlson EC, Wang IJ, Liu CY, et al (2003): Altered KSPG expression by keratocytes following corneal injury. Mo Vis, 9, 615-623.

3. Catalanotti P, Lanza M, Del Prete A, et al (2005): Slimeproducing Staphylococcus epidermidis and S. aureus in acute bacterial conjunctivitis in soft contact lens wearers. New Microbiol, 28, 345-354.

4. Cintron C, Kublin CL, Covington H (1981): Quantitative studies of corneal epithelial wound healing in rabbits. Curr Eye Res, 1, 507-516.

5. Eshar D, Wyre NR, Schoster J V (2011): Use of collagen shields for treatment of chronic bilateral corneal ulcers in a pet rabbit. J Small Ani Pract, 52, 380-383.

6. Fan T, Zhao J, Hu X, et al (2011): Therapeutic efficiency of tissue-engineered human corneal endothelium transplants on rabbit primary corneal endotheliopathy. J Zhejiang Univ Sci B, 12, 492-498.

7. Frantz JM, Dupuy BM, Kaufman HE, et al (1989): The effect of collagen shields on epithelial wound healing in rabbits. Am J Ophthalmol, 108, 524-528.

8. Fu Y, Fan X, Chen P, et al (2010): Reconstruction of a tissue-engineered cornea with porcine corneal acellular matrix as the scaffold. Cells Tissues Organs, 191, 193-202.

9. Gasset AR, Kaufman HE (1970): Therapeutic uses of hydrophilic contact lenses. Am J Ophthalmol, 69, 252-259.

10. Gelatt KN, Gilger BC, Kern TJ (2013): Veterinary Ophthalmology. John Wiley\&Sons, Inc., Iowa.

11. Günay C, Sağlıyan A, Yaman M (2005): Köpeklerde deneysel olarak oluşturulan korneal defektlerin sağaltıminda asetilsisteinin etkisi. Frrat Üni Sağ Bil Vet Derg, 19, 151-156.

12. Honda N (2009): Descemet tripping automated endothelial keratoplasty using cultured corneal endothelial cells in a rabbit model. Arch Ophthalmol, 127, 1321.

13. Kanao S, Kouzuki S, Tsuruno M, et al (1993): Clinical application of $3 \% \mathrm{~N}$-acetylcysteine collyrium on canine corneal diseases. J Japan Vet Med Assoc, 46, 487-491.

14. Klyce FD Beuerman RW (1988): Structure and function of the cornea. 3-54. In: HE Kaufman, BA Barron, MB McDonald (Eds), The Cornea. Churchill Livingstone, New York.
15. Kuwabara T, Perkins DG, Cogan DG (1976): Sliding of the epithelium in experimental corneal wounds. Invest Ophthalmol, 15, 4-14.

16. La Croix NC, Van Der Woerdt A, Olivero DK (2001): Nonhealing corneal ulcers in cats: 29 cases (1991-1999). J Am Vet Med Assoc, 218, 733-735.

17. Lesar TS, Fiscella RG (1985): Antimicrobial drug delivery to the eye. Drug Intell Clin Pharm, 19, 642-654.

18. Marmer RH (1988): Therapeutic and protective properties of the corneal collagen shield. J Cataract Refract Surg, 14, 496-499.

19. Marsich MM, Bullimore MA (2000): The repeatability of corneal thickness measures. Cornea, 19, 792-795.

20. Martin CL, Pickett JP (2019): Ophthalmic Disease In Veterinary Medicine. CRC Press/Taylor \& Francis Group, New York.

21. Meek KM, Knupp C (2015): Corneal structure and transparency. Prog Retin Eye Res, 49, 1-16.

22. Mimura T, Yamagami S, Yokoo S, et al (2005): Sphere therapy for corneal endothelium deficiency in a rabbit model. Invest Opthalmol Vis Sci, 46, 3128.

23. Nagata M, Nakamura T, Hata Y, et al (2015): JBP485 promotes corneal epithelial wound healing. Sci Rep, 5, 14776.

24. Nakamura Y, Nakamura T, Tarui T, et al (2012): Functional role of PPARS in corneal epithelial wound healing. Am J Pathol, 180, 583-598.

25. Oltulu R, Şatirtav G, Donbaloğlu M, et al (2014): Intraoperative corneal thickness monitoring during corneal collagen cross-linking with isotonic riboflavin solution with and without dextran. Cornea, 33, 1164-1167.

26. Perran G (1989): Karnivorlarda (köpek ve kedi) ulkus kornea olgularinin sagaltıminda subkonjunktival alfakimotripsin enzimi uygulamaları. Ankara Univ Vet Fak Derg, 36, 704-721.

27. Poland DE, Kaufman HE (1988): Clinical uses of collagen shields. J Cataract Refract Surg, 14, 489-491.

28. Robin JB, Keys CL, Kaminski LA, et al (1990): The effect of collagen shields on rabbit corneal reepithelialization after chemical debridement. Invest Ophthalmol Vis Sci, 31, 1294-1300.

29. Schulz D, Iliev ME, Frueh BE, et al (2003): In vivo pachymetry in normal eyes of rats, mice and rabbits with the optical low coherence reflectometer. Vision Res, 43, 723 728.

30. Shaker GJ, Ueda S, LoCascio JA, et al (1989): Effect of a collagen shield on cat corneal epithelial wound healing. Invest Ophthalmol Vis Sci, 30, 1565-68.

31. Sharma S (2011): Antibiotic resistance in ocular bacterial pathogens. Indian J Med Microbiol, 29, 218-222.

32. Simsek NA, Ay GM, Tugal-Tutkun I, et al (1996): $A n$ experimental study on the effect of collagen shields and therapeutic contact lenses on corneal wound healing. Cornea, 15, 612-616.

33. Stoop JWFM (1970): Treatment of pressure sores in paraplegic patients with animal collagen. Spinal Cord, 8 , $177-182$.

34. Willoughby CE, Batterbury M, Kaye SB (2002): Collagen corneal shields. Surv Ophthalmol, 47, 174-182. 